\title{
MELALUI MODEL PEMBELAJARAN STUDENT TEAMS ACHIEVEMENT DIVISION (STAD) UNTUK MENINGKATKAN HASIL BELAJAR KIMIA MATERI SIFAT GARAM YANG TERHIDROLISIS
}

\author{
Naini Afrita \\ SMA Negeri 1 Aceh Barat Daya \\ Jalan Pendidikan No. 92 Telp. (0659) 91028 Blang Pidie 23764 \\ Email: nainiafrita4@gmail.com
}

\begin{abstract}
Abstrak
Tujuan dari penelitian ini adalah untuk mengetahui hasil belajar siswa dan untuk meningkatkan keaktifan kelas melalui model pembelajaran Student Teams Achievement Division (STAD) pada materi Sifat garam yang terhidrolisis. Penelitian ini dilaksanakan dilaksanakan selama 3 bulan, dimulai pada bulan Januari hingga Maret 2021 di SMA Negeri 1 Aceh Barat Daya Tahun Ajaran 2020/2021. Adapun sampel yang digunakan penelitiannya meliputi siswa kelas XI IPA 1 berjumlah 36 siswa. Adapun penelitian ini terdiri atas 2 siklus. Setiap siklus terdiri atas perencanaan, pelaksanaan, pengamatan, dan refleksi. Simpulan pada penelitian ini berupa adanya peningkatan hasil belajar siswa pada mata pelajaran Kimia. Pada akhir siklus I, siswa yang mencapai ketuntasan belajar Kimia sebanyak $57,69 \%$ dan siswa yang belum tuntas sebanyak $42,31 \%$ sedangkan pada akhir siklus II didapati sebanyak $96,15 \%$ yang telah mencapai ketuntasan pada mata pelajaran ini. Pada hasil non tes, pengamatan proses belajar menunjukkan adanya perubahan siswa lebih aktif selama proses pembelajaran berlangsung.
\end{abstract}

Kata Kunci: Hasil Belajar, Model Pembelajaran, Student Teams Achievement Division (STAD)

\begin{abstract}
The purpose of this study was to determine student learning outcomes and to increase class activity through the Student Teams Achievement Division (STAD) learning model on the material of hydrolyzed salt properties. This research was carried out for 3 months, starting from January to March 2021 at SMA Negeri 1 Aceh Barat Daya for the 2020/2021 Academic Year. The sample used in this research includes students of class XI IPA 1 totaling 36 students. This research consists of 2 cycles. Each cycle consists of planning, implementation, observation, and reflection. The conclusion of this study is an increase in student learning outcomes in the subject of Chemistry. At the end of the first cycle, $57.69 \%$ of students who achieved mastery in studying Chemistry and $42.31 \%$ of students who had not completed the study were found, while at the end of the second cycle, it was found that $96.15 \%$ had achieved mastery in this subject. In the non-test results, the observation of the learning process showed a change in students being more active during the learning process.
\end{abstract}

Keyword: Learning Outcomes, Learning Models, Student Teams Achievement Division (STAD)

KATALIS Jurnal Penelitian Kimia dan Pendidikan Kimia

Vol. 4, No. 1, Juni 2021 


\section{PENDAHULUAN}

Pelaksanaan proses pembelajaran kimia selama ini, masih banyak dilaksanakan metode-metode yang bersifat klasikal dan belum mencapai outcomes yang memuaskan. Metode yang dijelaskan oleh guru selama ini masih bersifat teoritis dan belum kepada konsep pedagogiknya. Saat ini guru masih banyak memberikan catatan kepada para siswa dan tugas-tugas dalam bentuk latihan mengerjakan soal, maupun pekerjaan rumah. Proses pembelajaran tersebut terbukti hanya mampu mengantar siswa pada taraf penguasaan secara kognitif mengenai rumus-rumus kimia saja, serta kondisi ini siswa "dipaksa" untuk menghafal rumusrumus dan cara menggunakannya, tanpa ada pemahaman secara filosofis makna rumus-rumus dari konsep kimia yang sedang dipelajari, akibatnya akan segera lupa rumus yang dipelajari. (Ngang et al., 2014); (Jalilifar. 2010) perlunya metode yang baik agar memperoleh capaian yang baik bagi siswa. Jika kondisi pembelajaran semacam itu dibiarkan berlarut-larut, maka bukan tidak mungkin hasil belajar kimia akan terus berada pada arah yang rendah. Hal serupa pada penilitian Hempel et al., (2020); (Gillett \& Bayoumi, (1998) sering menghadapi kesulitan dalam memahami banyak konsep dasar dalam kimia sebagai bentuk kurangnya metode. Hal ini dapat mengakibatkan penurunan keberhasilan dan retensi siswa. Banyak faktor yang berperan dalam kualitas penguasaan suatu materi pokok pelajaran oleh siswa. Faktor-faktor tersebut bukan hanya faktor yang ada dalam setiap pribadi siswa, tetapi juga metode, strategi dan kreativitas seorang guru dalam menerapkan kegiatan pembelajaran. Selama ini kesan yang timbul di dalam diri siswa adalah bahwa kimia merupakan mata pelajaran yang sulit, sehingga tidak disukai. Gündüz \& Balyer, (2014); Tungkasamit et al., (2014) menyebautkan pentingnya sebuah inovasi dalam metode mengajar bagi guru dalam mengembangkan pembelajaran untuk menunjang suksesnya dan berhasilnya sebuah penyampaian materi pada siswa

Adanya pembelajaran yang baik memberikan jawaban atas tantangan kelas, hingga menunjang pengetahuan akademik, bahkan keterampilan teknis dan non-teknis (Perrenot et al., 2020); (Azlan et al., 2020). Maka dari itu guru dituntut untuk mampu untuk menghadapi tantangan pada era globalisasi saat ini dimana pendidikan harus berorientasi sesuai dengan kondisi dan tuntutan itu, agar output pendidikan dapat mengikuti perkembangan yang terjadi.

Dalam kondisi ini, pola penyelanggaraan pendidikan yang sama dalam berbagai kondisi lingkungan yang berbeda untuk berbagai lapisan masyarakat tidak bisa dipertahankan lagi. Dikatakan demikian, karena muatan dan proses pembelajaran di sekolah selama ini menjadi miskin variasi, berbasis pada standar nasional yang kaku. Pada penelitian Yan \& Burke, (2021); Mini et al., (2021) menjelaskan bahwa pentingnya metode dan inovasi dalam pembelajaran.

Disamping itu, peserta didik dievaluasi atas dasar akumulasi pengetahun yang telah diperolehnya, sehingga orang tua tidak mempunyai variasi pilihan atas jasa pelayanan pendidikan bagi anak-anaknya, sumbersumber pembelajaran di dunia nyata dan unggulan daerah tidak dimanfaatkan bagi kepentingan pendidikan di sekolah, dan lulusan hanya mampu menghafal tanpa memahami.

Berdasarkan observasi pendahuluan di lapangan, didapati peneliti dalam memberikan pembelajaran Kimia kepada siswa kelas XI.IPA.1 sebagian besar siswa sulit memahami materi sifat garam yang terhidrolisis terutama dalam menganalisis soal. Meskipun peneliti sudah berupaya membimbing siswa dalam memahami konsepnya, namun hasil belajar siswa belum sesuai dengan yang diharapkan, yaitu masih banyak siswa yang nilainya kurang dari standar ketuntasan belajar 
minimal 75 persen adapun dari 26 siswa kelas XI.IPA.1 tersebut, hanya 12 orang yakni 46 persen yang mencapai standar ketuntasan belajar minimal. Sedangkan yang lainnya masih belum mencapai dan harus diremedialkan.

Pembelajaran yang diberikan guru harus memiliki strategi dan model pembelajaran yang inovatif dan terarah, agar siswa dapat belajar secara efektif dan efisien, mengena pada tujuan yang diharapkan salah satu langkah untuk memiliki strategi itu ialah harus menguasai teknik-teknik penyajian. Perkembangan global saat ini juga menuntut dunia pendidikan untuk selalu mengubah konsep berpikirnya yang awalnya statis menuju keterampilan berpikir tingkat tinggi. Konsep lama mungkin sudah tidak sesuai dengan perkembangan saat ini, lebih-lebih untuk yang akan datang. Untuk itulah, perubahan selalu dilakukan sesuai dengan perkembangan zaman.

Pendidikan formal saat ini ditandai dengan adanya perubahan yang berkalikali dalam beberapa tahun terakhir ini ditandai dengan adanya suatu perubahan. Perubahan pada hakekatnya adalah sesuatu hal yang wajar karena perubahan itu adalah sesuatu yang bersifat kodrati dan manusiawi. Hanya ada dua alternatif pilihan yaitu menghadapi tantangan yang ada di dalamnya atau mencoba menghindarinya. Jika perubahan direspon positif akan menjadi peluang dan jika perubahan direspon negatif akan menjadi arus kuat yang menghempaskan dan mengalahkan kita.

Dalam proses pembelajaran yang menyangkut materi, metode, media alat peraga dan sebagainya harus juga memiliki kebaruan. Hal ini sejalan dengan penelitian Hempel et al. (2020) yang menyebutkan terkait kebaruan dalam mengajar. Dengan adanya kebaruan dalam metode tersebut, seorang guru harus lebih kreatif dan inovatif, terutama dalam menentukan model dan metode yang tepat akan sangat menentukan keberhasilan siswa. Dari permasalahan di atas, hasil belajar Kimia pada siswa kelas XI.IPA.1 materi Sifat garam yang terhidrolisis di SMA Negeri 1 Aceh Barat Daya, peneliti sendiri memiliki hipotesis yakni, adanya peningkatan keberhasilan kelas dapat dicapai salah satunya dengan model pembelajaran Student Teams Achievement Division (STAD) Untuk meningkatkan hasil belajar Kimia materi. Pada penelitian Amornsinlaphachai, (2014); Motaei, (2014); Özütürk \& Hürsen, (2014) menggunakan model STAD memberikan dampak baik bagi siswa, sehingga memperoleh capaian hingga 70,20 persen dari mata pelajaran yang disampaikan terserap oleh siswa.

\section{METODE PENELITIAN}

Penelitian dilaksanakan selama 3 bulan, dimulai bulan Januari sampai dengan bulan Maret 2021 yang dilaksanakan di SMA Negeri 1 Aceh Barat Daya, sementara untuk sampel adalah siswa kelas XI.IPA.1 Tahun 2021. Untuk teknik analisis deskriptif kualitatif, yaitu suatu metode penelitian yang bersifat menggambarkan kenyataan yang aktual.

Analisis ini dihitung dengan menggunakan statistik sederhana yaitu:

1. Untuk menilai ulangan atu tes formatif

Peneliti melakukan penjumlahan nilai yang diperoleh siswa, yang selanjutnya dibagi dengan jumlah siswa yang ada di kelas tersebut sehingga diperoleh rata-rata tes formatif dapat dirumuskan:

$$
\begin{aligned}
& \bar{X}=\frac{\sum X}{\sum N} \\
& \text { Dengan }: \bar{X}=\text { Nilai rata-rata } \\
& \Sigma \mathrm{X}=\text { Jumlah semua nilai siswa } \\
& \Sigma \mathrm{N}=\text { Jumlah siswa }
\end{aligned}
$$

2. Untuk ketuntasan belajar

Ada dua kategori ketuntasan belajar yaitu secara perorangan dan secara klasikal. seorang siswa telah tuntas belajar 
bila telah mencapai skor 75 persen atau nilai 75 , dan kelas disebut tuntas belajar bila di kelas tersebut terdapat 85 persen yang telah mencapai daya serap lebih dari sama dengan 85 persen. Untuk menghitung persentase ketuntasan belajar digunakan rumus sebagai berikut:

$$
P=\frac{\sum \text { Siswa.yang.tuntas.belajar }}{\sum \text { Siswa }} \times 100 \%
$$

\section{HASIL PENELITIAN DAN PEMBAHASAN Deskripsi Kondisi Awal}

Kondisi Prasiklus untuk kemampuan siswa dalam menguasai pelajaran Kimia di kelas XI.IPA-1 SMA Negeri 1 Aceh Barat Daya sangat kurang. Siswa kelas XI.IPA-1 sebagai subyek penelitian ini memiliki karakteristik yang heterogen. Dari segi watak ada beberapa siswa yang memiliki watak sulit diatur, sehingga kadang-kadang menyulitkan guru pada saat pembelajaran berlangsung. Namun secara umum memiliki kepribadian yang cukup baik.

\section{Tabel 1. Hasil Rekap Nilai Tes Prasiklus}

\begin{tabular}{|c|c|c|l|c|c|}
\hline $\begin{array}{c}\text { N } \\
\text { o }\end{array}$ & $\begin{array}{c}\text { Hasil } \\
\text { Angka }\end{array}$ & $\begin{array}{c}\text { Hasil } \\
\text { huruf }\end{array}$ & $\begin{array}{c}\text { Arti } \\
\text { Lambang }\end{array}$ & $\begin{array}{c}\text { Jumlah } \\
\text { Siswa }\end{array}$ & Persen \\
\hline $\mathbf{1}$ & $\mathbf{9 0 - 1 0 0}$ & A & S baik & - & $\mathbf{0 \%}$ \\
\hline $\mathbf{2}$ & $\mathbf{8 0 - 8 9}$ & B & Baik & 4 & $\mathbf{5 , 3 8 \%}$ \\
\hline $\mathbf{3}$ & $\mathbf{7 0 - 7 9}$ & C & Cukup & $\mathbf{8}$ & $\mathbf{3 0 , 7 6 \%}$ \\
\hline $\mathbf{4}$ & $\mathbf{6 0 - 6 9}$ & D & Kurang & 7 & $\mathbf{6 , 9 2 \%}$ \\
\hline $\mathbf{5}$ & $<59$ & E & S Kurang & 7 & $\mathbf{6 , 9 2 \%}$ \\
\hline \multicolumn{7}{|c}{ Jumlah } \\
\hline
\end{tabular}

Berdasarkan hasil analisis dalam tabel di atas diketahui bahwa jumlah siswa yang mendapat nilai A (sangat baik) sejumlah 0 persen atau tidak ada, yang mendapat nilai B (baik) sebanyak 15,38 persen atau sebanyak 4 siswa dan yang mendapat nilai $\mathrm{C}$ (cukup) sebanyak 30,76 persen atau 8 siswa, dan yang mendapat nilai kurang 26,92 persen atau sebanyak 7 siswa, sedangkan yang mendapat nilai sangat kurang 26,92 persen atau sebanyak 7 siswa.

\section{Deskripsi Hasil Siklus I}

\section{a. Perencanaan Tindakan}

1) Menyusun perencanaan langkahlangkah penelitian yang akan dilaksanakan bersama dengan guru serumpun agar guru serumpun yang bertugas sebagai observer mengatahui dan memahami langkah-langkah penelitian pembelajaran model Student Teams Achievement Division (STAD). 2) Menentukan materi yang akan dijadikan materi atau standar kompetensi yang dijadikan bahan penelitian. Materi yang dijadikan bahan penelitian materi Sifat garam yang terhidrolisis karena materi ini termasuk materi yang sulit dimengerti sebagian besar siswa.

3). Mengembangkan format evaluasi yang berupa tes akhir siklus dengan bentuk soal uraian berstruktur bertujuan untuk melihat proses pemikiran langkah demi langkah. 4). Menyusun Lembar Kerja yang berupa soal-soal yang akan diselesaikan oleh tiap kelompok dan menyusun kuis untuk mengukur peningkatan individu.

5). Mengembangkan format observasi pembelajaran yang terdiri dari observasi kegiatan guru dan observasi kegiatan siswa selama kegiatan belajar mengajar dengan model pembelajaran model Student Teams Achievement Division (STAD).

\section{Pelaksanaan Tindakan}

Sesuai dengan rencana, pembelajaran Kimia dilakukan dengan menggunakan model pembelajaran kooperatif model Student Teams Achievement Division (STAD). Pelaksanaan tindakan pada siklus I dilaksanakan dalam dua kali pertemuan sebagai berikut:

1. Guru mengadakan presensi terhadap kehadiran siswa.

2. Guru menyampaikan tujuan pembelajaran sesuai dengan materi yang diajarkan.

3. Guru menyampaikan kompetensi dasar dan menginformasikan model pembelajaran yang akan 
digunakan serta langkah-langkah penyajian kelas, diskusi kelompok, presentasi, kuis.

4. Guru memberikan pekerjaan rumah atau tugas terstruktur untuk memperdalam pemahaman materi yang diajarkan.

\section{Observasi}

Observasi dilakukan untuk mengetahui sejauh mana keterlaksanaan pembelajaran dengan menggunakan model pembelajaran kooperatif Student Teams Achievement Division (STAD). Hasil pengamatan siklus I oleh Satu orang observer, didapatkan bahwa dalam melaksanakan pembelajaran dengan model pembelajaran kooperatif model Student Teams Achievement Divisions (STAD) guru telah menerapkannya sesuai dengan Rencana Pelaksanaan Pembelajaran (RPP) dan langkah-langkah model pembelajaran kooperatif model Student Teams Achievement Division (STAD) tentang Sifat garam yang terhidrolisis.

\section{Hasil Pengamatan}

Hasil pengamatan pada siklus I dapat dideskripsikan seperti pada tabel berikut ini. Untuk memperjelas data hasil tes siklus I dapat dilihat pada tabel berikut ini:

Tabel 2. Hasil Rekap Nilai Tes Siklus I

\begin{tabular}{|c|c|c|c|c|c|}
\hline No & $\begin{array}{c}\text { Hasil } \\
\text { Angka }\end{array}$ & $\begin{array}{l}\text { Hasil } \\
\text { Huruf }\end{array}$ & $\begin{array}{c}\text { Arti } \\
\text { Lambang }\end{array}$ & $\begin{array}{c}\text { Jumlah } \\
\text { Siswa }\end{array}$ & Persen \\
\hline 1 & $90-100$ & A & $\mathrm{S}$ baik & 2 & $7,69 \%$ \\
\hline 2 & $80-89$ & B & Baik & 5 & $9,23 \%$ \\
\hline 3 & $60-79$ & $\mathrm{C}$ & Cukup & 8 & $30,76 \%$ \\
\hline 4 & $50-69$ & $\mathrm{D}$ & Kurang & 7 & $26,92 \%$ \\
\hline 5 & $<59$ & E & S Kurang & 4 & $15,38 \%$ \\
\hline \multicolumn{4}{|c|}{ Jumlah } & 26 & $100 \%$ \\
\hline
\end{tabular}

Dari hasil tes siklus I, menunjukkan bahwa hasil yang mencapai nilai A (sangat baik) adalah 2 siswa yakni 7,69 persen, sedangkan yang mendapat nilai B (baik) adalah 5 siswa atau 19,23 persen, sedangkan dari jumlah 26 siswa yang masih mendapatkan nilai $\mathrm{C}$ (cukup) sebanyak 8 siswa atau 30,76 persen, sedangkan yang mendapat nilai D (kurang) ada 7 siswa dengan persentase 26,92 persen, sedangkan yang mendapat nilai $\mathrm{E}$ (sangat kurang) ada 4 siswa atau 15,38 persen.

\section{Refleksi}

Berdasarkan hasil tes hasil siklus I dapat dilihat masih banyak terdapat jumlah siswa yang berada di bawah Kriteria Ketuntasan Minimal (KKM). Berdasarkan data pada tabel di atas, dapat disimpulkan bahwa pembelajaran menggunakan model Student Teams Achievement Division (STAD) belum mampu meningkatkan hasil belajar, khususnya pada materi Sifat garam yang terhidrolisis. Walaupun sudah terjadi kenaikan seperti tersebut di atas, namun hasil tersebut belum optimal. Hal ini dapat terlihat dari hasil observasi bahwa dalam kegiatan pembelajaran masih terdapat beberapa siswa yang kurang aktif dalam melakukan kegiatan pembelajaran, karena sebagian siswa beranggapan bahwa kegiatan secara kelompok akan mendapat hasil yang sama. Oleh karena itu, diperlukan upaya perbaikan pembelajaran pada siklus II.

\section{Deskripsi Hasil Siklus II}

Berdasarkan hasil refleksi pada siklus I, maka pelaksanaan tindakan pada siklus II dapat dideskripsikan sebagai berikut.

\section{Perencanaan Tindakan}

Berdasarkan hasil refleksi yang dilakukan pada siklus I maka pada siklus II telah dibuat beberapa tindakan untuk memperbaiki dan mengurangi kendala yang terjadi selama pelaksanaan pembelajaran siklus I. Untuk pelaksanaan pembelajaran siklus II berjalan lebih baik maka peneliti.

a) menyiapkan dan menyususun RPP per pertemuan dengan kompetensi dasar " Sifat garam yang terhidrolisis". 
b) Menyusun Soal kuis yang disesuikan dengan indikator pencapaian pada RPP yang telah disusun.

c) Menyusun Jurnal siswa untuk mengetahui motivasi dan aktivitas siswa dalam mengikuti proses belajar mengajar dengan model pembelajaran Student Teams Achievement Division (STAD).

d) Menyusun angket sikap siswa untuk mengetahui tanggapan siswa terhadap proses pembelajaran Kimia dengan model pembelajaran Student Teams Achievement Division (STAD).

e) Menyusun dan mengembangkan alat evaluasi atau test siklus II untuk mengetahui ketercapaian prestasi/ ketuntasan perorangan dan klasikal setelah menerima tindakan siklus II.

\section{Pelaksanaan Tindakan}

Berdasarkan rencana yang telah disusun, pembelajaran Kimia pada siklus II dilakukan dengan menggunakan model pembelajaran Student Teams Achievement Division (STAD). Pelaksanaan tindakan pada siklus II dilaksanakan dalam dalam satu kali pertemuan sebagai berikut:

a) Guru mengadakan presensi terhadap kehadiran siswa.

b) Guru menyampaikan tujuan pembelajaran sesuai dengan materi yang diajarkan.

c) Guru menyampaikan kompetensi dasar dan menginformasikan model pembelajaran yang akan digunakan serta langkah-langkah penyajian kelas, diskusi kelompok, presentasi, kuis.

d) Guru memberikan pekerjaan rumah atau tugas terstruktur untuk memperdalam pemahaman materi yang diajarkan.

\section{Observasi}

Berdasarkan hasil observasi dari observer bahwa pembelajaran telah terlaksana sesuai dengan yang direncanakan dan berjalan dengan baik. Pada saat diskusi kelompok berlangsung, jika salah satu anggota kelompok bisa memahami masalah pada soal yang diberikan, maka siswa tersebut membantu anggota yang lain untuk menjelaskan permasalahan yang dihadapi. Beberapa kelompok telah memanfaatkan waktu yang diberikan untuk melakukan diskusi dengan anggota kelompoknya.

\section{Hasil Pengamatan}

Hasil pengamatan pada siklus II dapat dideskripsikan seperti pada tabel berikut ini:

Tabel 3. Rekap Hasil Nilai Tes Siklus II

\begin{tabular}{|l|l|c|l|c|c|}
\hline $\begin{array}{c}\text { N } \\
\text { o }\end{array}$ & $\begin{array}{c}\text { Hasil } \\
\text { Angka }\end{array}$ & $\begin{array}{c}\text { Hasil } \\
\text { Huruf }\end{array}$ & $\begin{array}{c}\text { Arti } \\
\text { Lamba } \\
\text { ng }\end{array}$ & $\begin{array}{c}\text { Jmlh } \\
\text { Siswa }\end{array}$ & Persen \\
\hline 1 & $90-100$ & A & Baik & 6 & $\begin{array}{c}23,08 \\
\%\end{array}$ \\
\hline 2 & $80-89$ & B & Baik & 12 & $\begin{array}{c}46,15 \\
\%\end{array}$ \\
\hline 3 & $70-73$ & C & Cukup & 7 & $\begin{array}{c}26,92 \\
\%\end{array}$ \\
\hline 4 & $60-69$ & D & Kurang & 1 & $3,85 \%$ \\
\hline 5 & $<59$ & E & $\begin{array}{l}\text { S } \\
\text { Kurang }\end{array}$ & - & - \\
\hline \multicolumn{7}{|c|}{ Jumlah } & $\mathbf{2 6}$ & $\mathbf{1 0 0 \%}$ \\
\hline
\end{tabular}

Dari tabel di atas dapat diketahui bahwa yang mendapatkan nilai sangat baik (A) adalah 23,08 persen atau 6 siswa, sedangkan yang terbanyak yaitu yang mendapat nilai baik (B) adalah 46,15 persen atau 12 siswa. Dan yang mendapat nilai $C$ (cukup) adalah 26,92 persen atau sebanyak 7 siswa. Sedangkan yang mendapat nilai $\mathrm{D}$ ada 1 siswa atau 3,85 persen dan E tidak ada.

\section{Refleksi}

Refleksi dilakukan oleh peneliti dengan rekan guru satu rumpun sebagai observer setelah pelaksanaan pembelajaran pada siklus II berkhir. Dari refleksi menunjukan bahwa pelaksanaan 
pembelajaran pada siklus II relatif lebih baik dari pada pelaksanaan pembelajaran siklus I. Hal tersebut dapat dilihat dari peningkatan rata-rata nilai pada tiap pertemuan.

Tabel 4. Perbandingan Hasil Nilai Tes Siklus I dan Siklus II

\begin{tabular}{|c|c|c|c|c|}
\hline \multirow{2}{*}{ No } & \multirow{2}{*}{ Hasil Tes } & \multicolumn{3}{|c|}{$\begin{array}{c}\text { Jumlah Siswa yang } \\
\text { Berhasil }\end{array}$} \\
\cline { 3 - 5 } & & Prasiklus & $\begin{array}{c}\text { Siklus } \\
\text { I }\end{array}$ & $\begin{array}{c}\text { Siklus } \\
\text { II }\end{array}$ \\
\hline 1 & A (90-100) & - & 2 & 6 \\
\hline 2 & B (80-89) & 4 & 5 & 12 \\
\hline 3 & C (70-79) & 8 & 8 & 7 \\
\hline 4 & D (60-69) & 7 & 7 & 1 \\
\hline 5 & E (<59) & 7 & 4 & - \\
\hline \multicolumn{2}{|c|}{ Jumlah } & $\mathbf{2 6}$ & $\mathbf{2 6}$ & $\mathbf{2 6}$ \\
\hline
\end{tabular}

Atas dasar informasi pada tabel di atas, dapat disimpulkan bahwa pembelajaran menggunakan model Student Teams Achievement Division (STAD) khususnya pada penguasaan mater Sifat garam yang terhidrolisis ada peningkatan.

\section{Pembahasan}

Berdasarkan deskripsi hasil penelitian yang telah diuraikan sebelumnya, dapat diketahui bahwa penerapan model pembelajaran kooperatif model Student Teams Aachievement Divisions (STAD) dapat meningkatkan aktivitas atau hasil belajar siswa dalam belajar Kimia terbukti naiknya ketuntasan belajar siswa pada konsep Sifat garam yang terhidrolisis.

Berdasarkan hasil dari jurnal siswa yang diberikan setiap akhir siklus untuk mengetahui motivasi serta aktivitas siswa terhadap pembelajaran Kimia dengan model pembelajaran kooperatif model Sudent Teams achievement Divisions (STAD).

\section{Pembahasan Siklus I}

Hasil tindakan pembelajaran pada siklus I, berupa hasil tes dan non tes. Berdasarkan hasil observasi yang dilakukan oleh peneliti terhadap pelaksanaan siklus I diperoleh keterangan sebagai berikut:

\section{a) Hasil belajar}

Dari hasil tes siklus I, menunjukkan bahwa hasil yang mencapai nilai A (sangat baik) adalah 2 siswa (7,69 persen), sedangkan yang mendapat nilai B (baik) adalah 5 siswa atau (19,23 persen), sedangkan dari jumlah 26 siswa yang masih mendapatkan nilai $\mathrm{C}$ (cukup) sebanyak 8 siswa (30,76 persen), sedangkan yang mendapat nilai D (kurang) ada 7 siswa (26,92 persen), sedangkan yang mendapat nilai $\mathrm{E}$ (sangat kurang) ada 4 siswa atau 15,38 persen.

Berdasarkan ketuntasan belajar siswa dari sejumlah 26 siswa terdapat 15 atau 57,69 persen yang sudah mencapai ketuntasan belajar. Sedangkan 11 siswa atau 42,31 persen belum mencapai ketuntasan.

\section{b) Proses Pembelajaran}

Proses pembelajaran pada siklus I sudah menunjukkan adanya perubahan, meskipun belum semua siswa terlibat aktif dalam kegiatan pembelajaran. Hal ini dikarenakan kegiatan yang bersifat kelompok ada anggapan bahwa hasil maupun nilai yang didapat secara kelompok. Dari hasil pengamatan telah terjadi kreatifitas dan keaktifan siswa secara mental maupun motorik, karena kegiatan pembelajaran yang dilakukan dengan kelompok serta perlu kecermatan dan ketepatan. Ada interaksi antar siswa secara individu maupun kelompok, serta antar kelompok. Masing-masing siswa ada peningkatan latihan bertanya dan menjawab antar kelompok, sehingga terlatih keterampilan bertanya jawab. Terjalin kerjasama inter dan antar kelompok. Ada persaingan positif antar kelompok mereka saling berkompetisi untuk memperoleh penghargaan dan menunjukkan untuk jati diri pada siswa.

Dari hasil refleksi siklus I dapat disimpulkan bahwa melalui penerapan pembelajaran menggunakan model Student Teams Achievement Division (STAD), 
siswa mengalami peningkatan baik dalam mencapai ketuntasan belajar maupun proses belajar, tetapi pada siklus I ini belum semua siswa mencapai ketuntasan karena ada sebagian siswa berpandangan bahwa kegiatan yang bersifat kelompok, penilaiannya pun juga kelompok.

\section{Pembahasan Siklus II}

Hasil tindakan pembelajaran pada siklus II berupa hasil tes dan non tes, Berdasarkan hasil observasi yang dilaksanakan oleh peneliti terhadap pelaksanaan siklus II diperoleh keterangan sebagai berikut.

\section{a) Hasil belajar}

Dari pelaksanan tindakan siklus II dapat diketahui bahwa yang mendapatkan nilai sangat baik (A) adalah 23,08 persen atau 6 siswa, sedangkan yang terbanyak yaitu yang mendapat nilai baik (B) adalah 46,15 persen atau 12 siswa. Dan yang mendapat nilai $C$ (cukup) adalah 26,92 persen atau sebanyak 7 siswa. Sedangkan yang mendapat nilai $D$ ada 1 siswa atau 3,85 persen dan E tidak ada. Berdasarkan ketuntasan belajar diketahui bahwa siswa yang mencapai ketuntasan sebanyak 25 siswa atau 96,15 persen yang berarti sudah ada peningkatan dibandingkan pada siklus I.

\section{b) Proses Pembelajaran}

Proses pembelajaran pada siklus II sudah menunjukkan semua siswa terlibat aktif dalam kegiatan pembelajaran. Hal ini dikarenakan sekalipun kegiatan bersifat kelompok namun ada tugas individual yang harus dipertanggung jawabkan, sehingga ada kompetisi kelompok maupun kompetisi individu. Dari hasil pengamatan telah terjadi kreatifitas dan keaktifan siswa secara mental maupun motorik, karena kegiatan pembelajaran yang dilakukan dengan presentasi langsung didepan kelas perlu kecermatan, ketepatan dan penghayatan. Ada interaksi antar siswa secara individu maupun kelompok, serta antar kelompok. Masing-masing siswa ada peningkatan latihan bertanya jawab dan bisa mengkaitkan dengan mata pelajaran lain maupun pengetahuan umum, sehingga disamping terlatih keterampilan bertanya jawab, siswa terlatih berargumentasi. Ada persaingan positif antar kelompok untuk penghargaan dan menunjukkan jati diri pada siswa.

Hasil antara siklus I dengan siklus II ada perubahan secara signifikan, hal ini ditandai dengan peningkatan jumlah siswa yang mencapai ketuntasan belajar. dari hasil tes akhir siklus II ternyata lebih baik dibandingkan dengan tingkat ketuntasan belajar siswa pada siklus I. Dengan melihat perbandingan hasil tes siklus I dan siklus II ada peningkatan yang cukup signifikan, baik dilihat dari ketuntasan belajar maupun hasil perolehan nilai rata- rata kelas. Dari sejumlah 24 siswa masih ada 2 siswa yang belum mencapai ketuntasan, hal ini memang siswa-siswa tersebut harus mendapatkan pelayanan khusus, namun sekalipun 2 siswa ini belum mencapai ketuntasan, di sisi lain tetap bergairah dalam belajar. Sehingga dapat disimpulkan bahwa melalui penerapan pembelajaran menggunakan model Student Teams Achievement Division (STAD) dapat meningkatkan hasil belajar kimia khususnya materi sifat garam yang terhidrolisis.

\section{PENUTUP}

\section{Kesimpulan}

1. Penerapan pembelajaran model Student Teams Achievement Division (STAD) dapat meningkatkan hasil belajar siswa mata pelajaran Kimia khususnya materi sifat garam yang terhidrolisis bagi siswa kelas XI.IPA-1 Semester 1 SMA Negeri 1 Aceh Barat Daya. Pada akhir siklus I, siswa yang mencapai ketuntasan belajar Kimia sebanyak 57,69 persen (15 siswa), dan siswa yang belum tuntas sebanyak 42,31 persen (11 siswa), sedangkan pada akhir siklus II, sebanyak 96,15 persen (25 siswa) yang telah mencapai ketuntasan dan sebanyak 3,85 persen 
(1 siswa) belum mencapai ketuntasan belajar kimia.

2. Adapun hasil non tes pengamatan proses belajar menunjukkan perubahan siswa lebih aktif selama proses pembelajaran berlangsung.

\section{Saran}

Berdasarkan penelitian yang telah dilakukan, peneliti mengajukan beberapa saran sebagai berikut :

1. Disarankan kepada guru agar tidak hanya menerapkan metode konvensional yaitu ceramah, guru juga perlu menggunakan metode pembelajaran yang lebih sesuai untuk membangkitkan minat belajar siswa serta memotivasi siswa dalam belajar.

2. Kreativitas guru perlu ditingkatkan untuk menjadikan model Student Teams Achievement Division (STAD) lebih menarik.

3. Diharapkan dari hasil penelitian untuk selanjutnya dapat diaplikasikan untuk materi-materi pokok pelajaran yang lainnya khususnya pelajaran Kimia.

\section{DAFTAR PUSTAKA}

Arends. 1997. Teori-teori Belajar. Jakarta: Erlangga.

Amornsinlaphachai, P. (2014). Designing a Learning Model Using the STAD Technique with a Suggestion System to Decrease Learners' Weakness. Procedia - Social and Behavioral Sciences, 116, 431-435. https://doi.org/10.1016/j.sbspro.201 4.01.235

Arikunto, Suharsimi. 2001. Dasar-dasar Evaluasi Pendidikan. Jakarta: Bina Aksara.

Azlan, C. A., Wong, J. H. D., Tan, L. K., Muhammad Shahrun, M. S. N.,
Ung, N. M., Pallath, V., Tan, C. P. L., Yeong, C. H., \& Ng, K. H. (2020). Teaching and learning of postgraduate medical physics using Internet-based e-learning during the COVID-19 pandemic - A case study from Malaysia. Physica Medica, 80, 10-16. https://doi.org/10.1016/j.ejmp.2020 .10 .002

Jalilifar, A. (2010). The effect of cooperative learning techniques on college students' reading comprehension. System, 38(1), 96-108. https://doi.org/10.1016/j.system.2 009.12.009

Gündüz, Y., \& Balyer, A. (2014). Examining Innovation Needs of Primary Schools: Teachers' Perceptions. Procedia - Social and Behavioral Sciences, 116, 139-143.

https://doi.org/10.1016/j.sbspro.2 014.01.181

Hempel, B., Kiehlbaugh, K., \& Blowers, P. (2020). Scalable and Practical Teaching Practices Faculty Can Deploy to Increase Retention: A Faculty Cookbook for Increasing Student Success. In Education for Chemical Engineers (Vol. 33, pp. 45-65). Elsevier B.V. https://doi.org/10.1016/j.ece.2020. 07.004

Muhibbah, 2009. Model pembelajaran Tipe STAD. Jakarta: Erlangga.

Mini, G. K., Sarma, P. S., Priya, C., \& Thankappan, K. R. (2020). Control of hypertension among teachers in schools in Kerala (CHATS-K), India. Indian Heart Journal, 72(5), 416-420. 
https://doi.org/10.1016/j.ihj.2020. 06.005

Mulyasa. 2006. Kurikulum Berbasis Kompetensi. Bandung : PT. Remaja Rosdakarya.

Ngang, T. K., Hong, C. S., \& Chanya, A. (2014). Collective Work of Novice Teachers in Changing Teaching Practices. Procedia Social and Behavioral Sciences, 116, 536-540. https://doi.org/10.1016/j.sbspro.20 14.01.254

Oemar Hamalik. 2003. Metode Mengajar dan Kesulitan-Kesulitan Belajar. Bandung: Tarsito.

Özütürk, G., \& Hürsen, Ç. (2014). Determination of University Students Motivation in EFL Classroom. Procedia - Social and Behavioral Sciences, 116, 7-12. https://doi.org/10.1016/j.sbspro.2014 .01 .159

Permendiknas No 41 tahun 2007, Kegiatan Pembelajaran Sesuai Standar Proses, Jakarta

Perrenot, C., Bresler, L., Berdah, S., Carretier, M., Faure, J. P., Frileux, P., Mabrut, J. Y., \& Beyer-Berjot, L. (2020). Development of a program for teaching practical skills in visceral and digestive surgery by simulation. In Journal of Visceral Surgery (Vol. 157, Issue 3, pp. S101-S116). Elsevier Masson SAS. https://doi.org/10.1016/j.jviscsurg.20 20.04.006

Rustiyah, N.K. 1991. Strategi Belajar Mengajar. Jakarta : Bina Aksara.
Sardiman. A. M. 1996. Interaksi dan Motivasi Belajar Mengajar. Jakarta : Bina Aksara.

Sudjana. N. 2002. Dasa-dasar Proses Belajar Mengajar. Bandung: PT Sinar Baru Algensindo.

T. A. Hasan Husein. 1983, Macam-Macam Metode Pembelajaran, Jakarta : Erlangga

Tungkasamit, A., Silanoi, L., Nethanomsak, T., \& Pimthong, P. (2014). Evaluation of School Activities for Developing the Desired Characteristics based on Sufficiency Economy Philosophy: A Project Report. Procedia - Social and Behavioral Sciences, 116, 541-546. https://doi.org/10.1016/j.sbspro.2014 .01 .255

Undang-undang No. 20 Tahun 2003 tentang Sistem Pendidikan Nasional. Jakarta : Depdiknas.

Joice dkk, Syaiful Bahri. 2002. Strategi Belajar Mengajar. Jakarta: Rineksa Cipta.

Yan, Y., \& Burke, M. (2021). School location, urban structure, and accessibility. In Urban Form and Accessibility (pp. 173-186). Elsevier. https://doi.org/10.1016/b978-0-12819822-3.00004-3 